\title{
Re-Calibrating Steampunk London: Heterotopia and Spatial Imaginaries in Assassins Creed: Syndicate and The Order 1886
}

\author{
Helena Esser
}

check for

updates

Citation: Esser, Helena. 2021.

Re-Calibrating Steampunk London:

Heterotopia and Spatial Imaginaries

in Assassins Creed: Syndicate and The

Order 1886. Humanities 10: 56.

https://doi.org/10.3390/h10010056

Received: 15 January 2021

Accepted: 17 March 2021

Published: 20 March 2021

Publisher's Note: MDPI stays neutral with regard to jurisdictional claims in published maps and institutional affiliations.

Copyright: (C) 2021 by the author. Licensee MDPI, Basel, Switzerland. This article is an open access article distributed under the terms and conditions of the Creative Commons Attribution (CC BY) license (https:// creativecommons.org/licenses/by/ $4.0 /)$.
Department of English, Theatre, and Creative Writing, Birkbeck, University of London, London WC1E 7HX, UK; helena.k.esser@gmx.de

\begin{abstract}
Video games have become important but understudied narrative media, which link into as well as perpetuate popular forms of cultural memory. They evoke and mediate space (or the illusion thereof) in unique ways, literally putting into play Doreen Massey's theory of space as being produced through a multiplicity of trajectories. I examine how Assassins Creed: Syndicate and The Order 1886 (both 2015) configure a neo-Victorian London as a simulated, spatio-temporal imaginary in which urban texture becomes a readable storytelling device in and of itself, and interrogate how their neo-Victorian heterotopias are mediated through a spatial experience. Both games conjure up imaginaries of steampunk London as a counter-site sourced from and commenting on the Victorian city of memory. Through retro-speculation, they re-calibrate neo-Victorian London as a playground offering alternative forms of agency and adventure or as cyberpunk-infused hyper-city. In so doing, they invite the player to re-evaluate, through their spatial experience in such a heterotopic steampunk London, shared imaginaries of 'the city' and 'the Victorian'.
\end{abstract}

Keywords: Assassin's Creed; cyberpunk; heterotopia; steampunk; The Order 1886; urban imaginaries; Victorian London; video games

\section{Introduction}

Very soon the face of London begins to convulse into a Freemason's wetdream of the City as a monologue of temples: parks and homes are demolished to make way for entrepreneurial edifices decorated with pharaonic runes and dedicated to Progress: new thoroughfares slice through the heart of town, steam gurneys choke the roadways and poison the air; and everywhere one can hear the sound of the new order being born. (Clute 1996, p. 234)

In reviewing William Gibson and Bruce Sterling's seminal 1990 novel The Difference Engine, John Clute, in the epigraph above, swiftly evokes how steampunk's anachronistic neo-Victorianism may quite literally re-create London as the archetypal Victorian city and so articulates an alternative history through urban space. Steampunk, by adding technofantastical impulses and retro-futurist speculation (Perschon 2018, pp. 2-12), collapses linear timelines, re-maps the Victorian urban imaginary of collective memory, and defamiliarises what Edward Soja calls "our mental and cognitive mapping of urban reality, and the interpretive grids through which we think about, experience, evaluate, and decide to act in these places, spaces, and communities in which we live" (Soja 2000, p. 324). In the steampunk city, Henri Levebvre's conception of space as socially produced (cf. Levebvre 1991, p. 26) converges with Frederic Jameson's notion of cognitive mapping as "a situational representation on the part of the individual subject to that vaster and properly unrepresentable totality which is the ensemble of society's structures as a whole" (Jameson 1991, p. 51) into a heterotopic thought experiment.

By re-organising the Victorian city through retro-speculative impulses, steampunk re-plays and re-imagines a socially produced and historically grown urban environment that both bears social and imagined legacies of the Victorian past yet must also answer 
to present-day demands and future projections. The steampunk city re-calibrates our "interpretive grids" and acts a heterotopic counter-site, "a kind of effectively enacted utopia in which the real sites, all the other real sites that can be found within the culture, are simultaneously represented, contested, and inverted" (Foucault 1984, p. 3).

It relies on our shared memory of the Victorian city to evoke, even mirror, the markers and conditions of a physical London, while simultaneously re-calibrating it through retrofuturistic impulses. It thereby activates the tension between the familiarity of memory (representation) and the excitement of anachronism (inversion) to challenge our imaginary of past and present city alike with alternative outcomes. After all, David Harvey, expanding on Levebvre's concept of the Right to the City as a collective right to shape the processes of urbanisation (Levebvre [1968] 1996), posits: "[W] hat kind of city we want cannot be divorced from the question of what kind of people we want to be" (Harvey 2012, p. 4). Like Foucault's heterotopia of illusion, steampunk cities both re-present and reflect on 'real' space. They may "create a space of illusion that exposes every real space [ ... ] as still more illusory" as literal simulations reminding us how urban spaces and neo-Victorian imaginaries alike rely on shared iconographies and mental maps while also playing with our expectations (Foucault 1984, p. 8). As Soja notes in his discussion of Foucault, heterotopias are "also "other than" the established ways of thinking spatially. They are meant to detonate, to deconstruct, not to be comfortably poured back into old containers" (Soja 2000, p. 163). At the same time, steampunk cities may appear, like heterotopias of compensation, "as perfect, as meticulous, as well arranged as ours is messy, ill constructed, and jumbled" because they mimic the properties of real spaces while advertising their deviation from them as selling factor (Foucault 1984, p. 8). Foucault outlines "heterotopias of deviation", where "individuals whose behavior is deviant in relation to the required mean or norm are placed" (Foucault 1984, p. 5). As we will see, steampunk London becomes a space of adventure and exploration where such "deviants" as assassins and rebels become protagonist heroes. Lastly, steampunk London enacts the claim that the "heterotopia begins to function at full capacity when men arrive at a sort of absolute break with their traditional time" because it chronicles the Victorian era as urban archive and posits the entire city as heterotopic (Foucault 1984, p. 6). Sourced from a collective imaginary of the Victorian, steampunk represents neo-Victorian cities as "spaces in which memory is not just continually fostered, produced, and preserved, but also contested, deconstructed, and sometimes deliberately distorted or fabricated" (Kohlke and Gutleben 2015, p. 7). At the same time, they interrogate and contest that past through retro-speculation.

Traditionally, heterotopic spaces have been theorised as either physical or literary (see, for example, Dehane and Cauter 2008; Palladino and Miller 2015). Both come together in new ways in video game spaces, where fictional characters and plots are mediated through journeys through and interaction with simulated, but three-dimensional spaces modelled on real-life counterparts. As such, game spaces literally put heterotopias into play while also providing the closest to a 'real' approximation of steampunk cities, which are by definition impossible and fantastic (Perschon 2018, pp. 33-37). According to Espen Aarseth, space is video games' "defining element", as they "celebrate and explore spatial representation as a central motif and raison d'être" (Aarseth 2007, p. 44). As a neo-Victorian construct sourced from collective memory, game spaces must be considered an example of hyper-reality in line with Jean Baudrillard's simulacrum, which Soja defines as "a perfect copy of an original that may never have existed" and the "cumulative replacement of the real with its simulated representations or images" (Soja 2000, pp. 326-27). However, this very hyper-reality also illustrates how we collectively imagine the Victorian city: MarieLuise Kohlke and Christian Gutleben posit, after all, that "[i]n a sense, the neo-Victorian is by definition hyperreal, since it has no direct access to the Victorian real, instead relying entirely on Victorian texts and documents, that is, on signs of the past" (Kohlke and Gutleben 2012, p. 41).

In addition, game spaces are configured as three-dimensional: They "offload" the "cognitive overhead" of imagining space from text alone "into the machine", so that 
"gamers can focus on the flow of the game while learning the background mechanics through immersion and experimentation" (Carstocea 2017, p. 189), and we may interact with these simulated spaces by proxy through a digital avatar. What is more, cyberspace itself, a term coined in William Gibson's seminal cyberpunk novel Neuromancer (1984) and configured as a "consensual hallucination [ ... ] a graphic representation of data" that appears like "[l]ines of light ranged in the non-space of the mind, clusters and constellations of data. Like city lights receding ... " (Gibson [1984] 2016, p. 59), has been imagined from its infancy as "intrinsically spatial in [its] rhetoric and referencing", as well as "peculiarly urban" (Soja 2000, p. 336). Considering this affiliation between virtual space and the urban, and that Gibson co-authored The Difference Engine, a genre-shaping steampunk novel in which steampunk London assumes the qualities of one gigantic computer, it is perhaps no wonder that steampunk circles back, every now and then, and not least in video games, to its cyberpunk roots (cf. Luckhurst 2005, p. 219; Csiscery-Ronay 2011, p. 109).

In this essay, I examine how Assassins Creed: Syndicate (Ubisoft 2015) synthesises a Victorian London imaginary into an interactive virtual game space where the player may forge alternative, subjective relationships with the urban environment through the fantasy of the assassin figure. Here, neo-Victorian London becomes an interactive heterotopia of adventure, agency, and play, whose urban experience exposes the limitations and laws that govern its real counterpart. Against that backdrop, I consider The Order 1886 (Ready At Dawn 2015) as a game that productively 'punks' the cityscape through cyberpunk impulses and provides an immersive experience of heterotopia characterised by discovery and re-evaluation of the city and the collective neo-Victorian memory it enshrines. As such, The Order 1886 may illustrate how steampunk game spaces can be considered as doubly heterotopic: As virtual spaces that reflect and challenge real spaces, and as steampunk fictions that play with and comment on collective memory of the Victorian past.

\section{Producing a Virtual Steampunk London}

No city emblematises Victorian urban legacies as potently as London, which throughout the Victorian era remained the largest city in the world and became a collective symbol of the first megalopolis, and one configured in a distinct, quaintly Gothic, "weird and archaic" aesthetic (Sterling 2011, p. 13), which subsequent mega-cities, such as New York, Tokyo, or Shanghai, do not share. Indeed, many iconic structures which have become essential cornerstones of a shared London imaginary appeared during the nineteenth century, among them the Kensington Museum complex and colleges, Westminster Palace, Trafalgar Square, the British Museum, Victoria, Paddington, and Charing Cross stations, Tower Bridge, Bazalgette's embankment and sewer system, and the Underground. These structures have become markers of a shared cultural memory of nineteenth century London that frequently serve as landmarks in neo-Victorian texts.

A well-known canon of Victorian writers have tried to represent and account for, and in so doing shared in the creation of a London imaginary. Let us consider this the following scene from Charles Dickens' Nicholas Nickleby (1838-1839):

They rattled on through the noisy, bustling, crowded streets of London, now displaying long double rows of brightly-burning lamps, dotted here and there with the chemists glaring lights, and illuminated besides with the brilliant flood that streamed from the windows of the shops, where sparkling jewellery, silks and velvets of the richest colours, the most inviting delicacies, and most sumptuous articles of luxurious ornament, succeeded each other in rich and glittering profusion. Streams of people apparently without end poured on and on, jostling each other in the crowd and hurrying forward, scarcely seeming to notice the riches that surrounded them on every side; while vehicles of all shapes and makes, mingled up together in one moving mass, like running water, lent their ceaseless roar to swell the noise and tumult. (Dickens [1838] 1986)

Dickens' London here is experienced in transit and is produced through a succession of sensory impressions and indeed a network of interlinking movements. As such, it exemplifies Doreen Massey's concept of space as an ongoing process: "This is space as the sphere 
of dynamic simultaneity, constantly disconnected by new arrivals, constantly waiting to be determined (and therefore always undetermined) by the construction of new relations. It is always being made and always therefore, in a sense, unfinished" (Massey 2005, p. 107). Considering space a "product of a multitude of histories whose resonances are still there", histories buried as well as still being made, she argues that to travel through space is to "participate in its continuing production" (Massey 2005, p. 118). Journeying through the city like Dickens' characters, or indeed the avatar in a video game, means to actively create space as one of a "bundle of trajectories": "Arriving at a new place means joining up with, somehow linking into, the collection of interwoven stories of which that place is made" (Massey 2005, p. 119). In steampunk video games, our avatar likewise joins up and links into the narrative episodes laid out through the setting: "The moving perspective projection defines a film-like, interactive, space- and time-based narration, which enables the combination of commonly used reality-based design attributes and plot structures" (Götz 2007, p. 135). Our immersed exploration of the game space actively produces the neo-Victorian virtual space that comes into being.

However, games in the Assassins' Creed franchise also make active use of the map as a panoptic structuring device, and complement the immersed perspective. Whereas Victorian London was routinely mapped through a panoptic view that attempted to represent physical relationships like the 1851 Ordnance Survey, or represent social relations like Jon Snow's cholera map (1854) or Charles Booth's Poverty Map (1889-1893), the panoptic view, as Lynda Nead notes, "made the modern city legible and comprehensible" but "could never capture or contain the rapid growth of and changes in London" or "contain the city of memory and imagination" (Nead 2000, pp. 13 and 26). As Massey remarks, maps "position the observer, themselves unobserved, outside and above the object of the gaze" and give the impression that space is "a surface-that it is a sphere of completed horizontality" (Massey 2005, p. 107). Syndicate relies on the map's panoptic view only as supplement, but one that orients us in the virtual London by laying out familiar landmarks that we can link to their real life counterparts, establishing a dialogue between the real city and its heterotopic, neo-Victorian simulation. As such, the game evokes collective memory by interlinking literary traditions and empirical evaluations in ways that enhance our understanding of the city that is conjured up, but also draw our attention to its artificiality, thereby marking it more explicitly as a counter-site that represents, but may also contest or invert the real site (Foucault 1984, p. 3).

\section{History Is Our Playground: The Victorian Game Space of Assassins' Creed: Syndicate}

In Syndicate, the player, through the twin assassins Evie and Jacob Frye, attempts to dismantle the corrupting empire of the magnate Crawford Starrick, a stand-in for the 'Victorian' evils of colonialism and exploitative industrial capitalism who controls London's networks of trade, transport, and production through his street gang, 'the Blighters' (easily recognisable through red jackets). To go against Starrick, the game tells us, is to take on "the city itself", if not the world at large: "Whosoever controls London, controls the world" (MrBlockzGaming 2019). In taking on Starrick's city, we must assassinate his associates, free working children from dismal factories, re-conquer city territory with our own, green-attired street gang, 'the Rogues', or solve puzzles and complete assignments set by historical persons such as Alexander Graham Bell, Charles Dickens, Charles Darwin, Florence Nightingale, or Karl Marx, or hunt urban monsters Spring-Heeled Jack and Jack the Ripper. On a narrative level as well as a spatial one, the game configures Victorian London as a nexus of interlinked networks of power, movement, and production, as well as ongoing stories and journeys. Through our interaction, we link into these ongoing trajectories and participate in the construction of this hyper-real imaginary space. As is common in the Assassin's Creed franchise, the player's own journey involves unusual and exciting movements, such as sabotaging factories, sneaking across rooftops, into tunnels, and through secret laboratories and asylums, chase thieving street urchins, hijack and race 
horse-drawn carriages, zip-line across Westminster Palace, or find artifacts hidden on top of St. Paul's Cathedral, the Tower of London, or inside Buckingham Palace.

Of course, in positioning us as outlaws with the good intention to set right historical wrongs (and who, by the end of the game, will receive knighthoods from Queen Victoria), the game offers a neo-Victorian narrative which broadly simplifies complex socio-economic and political realities of the real nineteenth century (Nieslen 2015, n.p.). In line with the game's indulgence in "genre conventions, such as the swashbuckling adventure" (Makai 2018, p. 3), in which the complexities of the real world may momentarily cohere into clear choices, its neo-Victorian perspective pits us against a "repressive patriarchal regime" which is "convenient as it is morally and politically unambiguous" (Voigts-Virchow 2009, p. 122). The game streamlines its meta-historical narratives for a wide audience: Its success, in Jenkins' terms, "depends on its ability to map our preexisting [ . . . ] fantasies" (Jenkins 2007, p. 57).

At the same time, Syndicate's game space "is always serving the primary purpose of gameplay" (Aarseth 2007, p. 47). While as a simulacrum of a city of historical memory in keeping with Baudrillard's definition, it "no longer needs to be rational, because it no longer measures itself against either an ideal or negative instance" (Baudrillard [1981] 1983, p. 7), Assassin's Creed strives to synthesise a realist, believable representation with players' expectations and functional gameplay (cf. Webster 2019, n.p.). Re-created with the help of meticulous research and historical consultants, for example historian Judith Flanders (author of The Victorian City, 2012), and inspired by contemporary artists such as John Atkinson Grimshaw (cf. Davies 2015, p. 92), Syndicate's London is characterised by a "verisimilitudinous approach" to faithful representation and a realist "filmic reality effect" (Makai 2018, p. 11). It offers seven playable zones corresponding to the boroughs Westminster, the Strand, City of London, Whitechapel, Southwark, Lambeth, and the Thames, as extensively and intricately constructed game spaces with individual aesthetic identities that can be viewed at different times of the day and in different weather conditions. However, while important landmarks are all in the right place, individual streets might be re-scaled to allow for free-roaming, scaling, or carriage-chases, and where Victorian London has vanished or remains undocumented, the game creates a sort of 'filler architecture'. As Espen Aarseth notes: "Computer games are allegories of space: they pretend to portray space in ever more realistic ways but rely on their deviation from reality in order to make the illusion playable" (Aarseth 2007, p. 47). Paradoxically, Syndicate's London evokes a realistic-looking Victorian London, albeit in an allegorical way that no longer measures itself against the historical city, but instead our collective memory of it. It serves both as a heterotopia of illusion, an elaborate projection of shared (stereo)types about the Victorian city, and crafts a virtual city that is readable and structured by an internal narrative: "Video games are particularly successful when they combine a break with particular limitations of reality in some areas with a retention of reality in others, inviting both comparison with real life and with the spectacular" (Götz 2007, p. 135). Like the cinema in Foucault's third principle of heterotopia, game spaces conjure up foreign spaces that are both real-looking and spectacular through a "projection of a three-dimensional space", but it is the projection behind the screen that becomes itself heterotopic. Syndicate configures this heterotopic Victorian city as interactive experience, offering it up as an adventurous playground to be conquered by the player.

We do this as Evie and Jacob Frye, our twin avatars, who represent the assassin as a fantasy of urban mastery: With our physical prowess, secret knowledge, and access to forbidden routes, we move unencumbered by and independent from the social, economic, legal, and even physical networks of urban spacethat constrain others. We climb facades, traverse rooftops, zip-line across urban canyons, jump on and off of vehicles, and may remain hidden and anonymous even in the crowd. Navigating the city confidently and on multiple levels, we map out an alternative urban imaginary through our trajectories through it, playfully re-imagining urban structures like walls, windows, and rooftops as opportunities for experiment and subversion. 
As such, the game literally puts into play Henry Jenkins' claim that virtual reality is a response to contemporary urban existence, in which spaces of play are vanishing (cf. Jenkins 2007, p. 60). By re-creating Victorian London as a historical playground to be roamed, explored, and appropriated through our movements, the game assimilates the politics of parkour, created in the 1980s by Sebastian Foucan and David Belle in the Parisian suburbs. An "extreme and subversive engagement" with the urban landscape and "radical inhabitation" which seeks to challenge and redefine our "experience of embodiment and presence" (Daskalaki et al. 2008, p. 51), parkour seeks to re-imbue urban spaces with a sense of agency and purpose through a "dialogical relationship between the built environment and [the traceurs's] bodies and thus, challenge their subject positions" (Ameel and Tani 2012, p. 18). Traceurs or free runners climb, jump or somersault over, across, and against urban structures, and effectively adapt Massey's notion of the trajectory as actively creating space into ways of forming a personal, embodied, and rebellious relationship with urban space, designed to generate "the feeling of having a stake in a particular environment, even though one cannot claim legal ownership over it" (Ameel and Tani 2012, p. 18). Like our avatars in Syndicate, free runners re-claim urban space from its pre-designed functions and regulations, and in so doing "create a parallel city" of free play and adventure (Ameel and Tani 2012, p. 18). Their transient, subjective, and alternative urban experience may also be considered as heterotopic, because it remains connected to real urban structures while also challenging and subverting them and drawing attention to their constructed-ness. Here, instead of individual institutions or places, the entire city is configured as potentially heterotopic.

In Syndicate's virtual Victorian London, this radical alternative experience of spatial experience and production becomes accessible to a wide contemporary audience. Although this means parkour's radical potential is co-opted for commercial use, it also means that its subversive exploration is practised by more players on a larger scale, offering an embodiedby-proxy urban experience the real London does not provide. Indeed, today's London is not just controlled by traffic regulations, signage and CCTV, but also increasingly gentrified, designed through urban planning, and dominated by the hegemonic spaces of commerce and finance. In this context, it is telling that Ubisoft promoted the game through a real-life montage of traceurs in costume (Devinsupertramp 2015), and that the behind-the-scenes video reveals the many locations and instances where London's regulations curtailed the endeavour (TEAMSUPERTRAMP 2015). In Syndicate's Victorian city, none of these trappings and regulations exist, and heavily protected places such as Westminster Palace or Buckingham Palace can be climbed and claimed by our assassin avatars like all other spaces.

However, in the heterotopic game world at least, we may freely engage with a virtual Victorian London in subjective and alternative ways that neither the historical nor the contemporary city leave open to us. This is not least exemplified through by the Leap of Faith, a key movement available at certain high points of the city, such as the spires of Westminster Palace or St Paul's Cathedral, from where we may enjoy a unique, panoptic panorama before leaping with outstretched arms in a pose of dedication, power, and self-confidence into conveniently placed balls of hay (cf. Davies 2015, p. 183). Syndicate invites its players to form a unique relationship with a neo-Victorian London which is driven by their agency and allows them to discover/create city and era in tandem as an interactive adventure. It illustrates how virtual game spaces "can represent the past as it was, or as it never was, but they can also represent how players wish to remember it, revisiting or revising the past to make players yearn for it, and they can offer players the possibility of not only being there but of doing things there-of playing the past" (Whalen and Taylor 2008, p. 27). As such, the game fully exploits Massey's notion of the production of space through interlinking trajectories across multiple axes: Not only does the game space "give concrete shape to our memories and imaginings of the story world, creating an immersive environment through which we can wander and with which we can interact" (Jenkins 2007, p. 57), but this interaction may also take place in remote, inaccessible, hidden, or forbidden virtual spaces, as well as from a birds-eye perspective or up close. Our avatar becomes the primary 
agent in producing a truly alternative London, which is not just heterotopic due to the time-space it evokes or the textures and landmarks it offers, but also because of the way it is experienced.

\section{Here Be Lycans: Steampunk London in The Order 1886}

Unlike Syndicate, the action adventure game The Order 1886 (Ready At Dawn 2015) is more stringently story-driven, and while its impressive production value and cinematic aesthetic have been lauded, players lamented that the narrative does not leave enough room for free roaming and exploration. Nonetheless, I posit that the game fully explores the possibilities of a heterotopic steampunk London, and that its re-calibrated urban environment is crucial in assessing and experiencing the strength of steampunk itself.

The game's premise is that an ancient Order of Knights, here the literal knights of Arthur's Round Table, has over centuries fought a genetically divergent, 'half-breed' race of human shape shifters, while the knights' lives are prolonged by the healing Blackwater elixir derived from the Holy Grail. We encounter this Order in the era of the Industrial Revolution, in a "[n]eo-Victorian" London "braced with the scaffolding of a coming modernity" (Ellis and Weerasuriya 2015, p. 6), in which mankind is perceived to have achieved a definitive dominance over the darker forces of nature (here, lycans and, later, vampires) through the mastery of an emergent technology: Electricity, the railway, airships, experimental new weapons, wireless communication, etc. However, in the midst of this new age, an uprising originating in that epicentre of disenfranchisement, Whitechapel, is rebelling against the United India Company, which is of course a fictionalised extension of the East India Company which was disestablished in 1874 following the real-world Indian Mutiny (1857-1858). Our avatar Galahad, a member of this Order, endeavours to investigate and will, in the course of the game, discover wide-ranging conspiracies and corruption. The Order here synthesises popular markers of the Victorian era such as Medievalism, Gothic monstrosity, social unrest, and colonialism and projects it into a steampunked London, a socio-historical nexus and potent memory figure in which the real and the fictional intertwine and which can support and accommodate an unending variety of narratives. Jenkins' theories of game space apply here: Unlike Syndicate, which synthesises "stories or genre traditions already well known to visitors, allowing them to enter physically into spaces they have visited many times before in their fantasies", The Order presupposes that its players will be able to read its steampunked environment against the background of their "well-developed mental map of the spaces, characters and situations" associated with Victorian London (Jenkins, p. 57). In this way its steampunked city also provides a heterotopic commentary on our shared memory of the Victorian city: It is heterochronic, "linked to slices in time", constitutes an "absolute break with [ .. ] traditional time", but also accumulates and archives popular knowledge about Victorian London, albeit in defamiliarised ways (Foucault 1984, p. 6).

The game's own narrative centres on the figure of Grayson, or Sir Galahad, but unlike in Syndicate, we hardly use our avatar to roam across rooftops. On the contrary, the game begins in medias res with a flash forward, and we emerge from literal darkness into a dungeon in which Galahad is being held. We only gain knowledge of the setting little by little as Galahad breaks out, fights royal guards, and finally emerges onto a roof of Westminster Palace. As soon as we have gained orientation, Galahad is cornered by Order Knights (his own compatriots) and throws himself into the Thames, and the flash forward ends. What is a functional introduction to the gameplay also acts as a tonal promise: Here, we find no x-ray vision or miniature maps to facilitate our navigation, no frame narrative provides meta-narrative information, and no panoptic map orients us in between missions. Unlike Syndicate, this game seeks to provide a ground-level experience of urban space, even if that proves to be disorienting. Such a steampunked space is produced quite literally through our journey through it, without extraneous clues, thereby prompting a hermeneutic reading of virtual space that engages our collective memory of the Victorian city, but also provides new and unfamiliar markers for us to discover and read. It puts into 
play Kohlke and Gutleben's claim that, "[p]alimpsestically, we read the past city through the overlaid present, but conversely, we also read the present city backwards through the underlying and resurfacing past" (Kohlke and Gutleben 2015, p. 6). The Order's unguided experience of an unfamiliar space temporarily places us in a perspective of disorientation or crisis in relation to the society and the human environment of this game world, as well as the real one (Foucault 1984, p. 6). We move through an immersive heterotopia that is both familiar from collective memory, and fragmented or strange, forcing us to continually re-evaluate our knowledge of real spaces and real memory against this steampunk one, thereby making its heterotopic challenge and subversion of real-life spaces palpable and engaging.

Accordingly, when we look out over Galahad's shoulder onto a steampunk cityscape, we encounter a multitude of towering spires stretching into the distance, neo-Gothic skyscrapers that rise up to and above the iconic dome of St Paul's Cathedral, and zeppelins floating in the sky. This is a London evocatively conceived as "Victorian Blade Runner" (Ellis and Weerasuriya 2015, p. 139), and as such overlays the already heterotopic neo-Victorian imaginary with a second, also heterotopic aesthetic, namely that of the 1980s cyberpunk city. By projecting into the past as well as the once-future or at least an alternative present (Blade Runner (1984) is set in 2019), The Order constructs a steampunk London that represents, contests, and inverts real space from two different perspectives simultaneously (Foucault 1984, p. 3.).

\section{Narrative Environments}

Let us consider what the Blade Runner aesthetic adds to The Order's steampunk London and how that influences its heterotopic comment. Whereas London, the world's largest city throughout Queen Victoria's reign, encapsulates the metropolis of the industrial revolution, that imaginary migrated over to New York in the 1920s and 30s. New York's sleek art deco skyscrapers informed Fritz Lang's iconic aesthetic of the hyper-city in Metropolis (1927), a film that came to encapsulate and dominate both utopian and dystopian visions of the urban future until the 1980s, when it was re-imagined in Ridley Scott's cyberpunk cult film Blade Runner (1982). Here, a horizon-less urban sprawl dominated by brutalist skyscrapers creates an apocalyptic imaginary of over-population and climate catastrophe in a way that has become so "entrenched as the definitive screen depiction of the nightmare future city", that William Gibson, whose Neuromancer co-launched the cyberpunk subculture, could simply use "Blade Runnered" as a verb (Rowley 2005, p. 250; Brooker 2005, p. 13):

"Its imagery has become the standard visual iconography for the science fiction metropolis: super-tall buildings; poorly-lit streets and alleys; smog; rain; heavy industry belching fire into the sky; neon advertisements; overcrowding; ethnically diverse (that is, non-white) crowds; eclectic punk-inspired costumes and hairstyles; retrofitted buildings of varying architectural styles; scavenged props, and so on." (Rowley 2005, p. 250)

Notable urbanists, such as David Harvey, Edward Soja, Frederic Jameson, and Doreen Massey have referenced the film in their work and so helped enshrine Blade Runner's 2019 L.A., now no longer in the future, as the defining urban imaginary of the future megalopolis, legible through a labyrinthine endlessness of skyscrapers, dominating consumerism, and a heterogeneous, anarchic underbelly: "The postmodern aesthetic of Blade Runner is the result of recycling, fusion of levels, discontinuous signifiers, explosion of boundaries, and erosion" (Bruno 1987, p. 6). The cyberpunk city, with its monolithic towers, smog-filled sky, externalised real urban fears in intrinsically postmodern ways to the extent that Jameson considered cyberpunk to be the "supreme literary expression if not of postmodernism, then of late capitalism itself" (Jameson 1991, p. 419, original emphasis). In cyberpunk, global corporations take the place of nations, and their ruthless capitalism exiles the disenfranchised into a life of hustling on the fringes of the city, "like a deranged experiment in social Darwinism" (Gibson [1984] 2016, p. 8). Overpowering cityscapes dictate flow and movement in disorienting, constricting, and dominating ways, and only the invisible flows of data in the "bodiless exultation of cyberspace" (Gibson [1984] 2016, 
p. 6) seem to provide a liberating experience of free roaming-not unlike game spaces today.

If heterotopias are "counter-sites, a kind of effectively enacted utopia in which the real sites, all the other real sites that can be found within the culture, are simultaneously represented, contested, and inverted" (Foucault 1984, p. 3), Blade Runner's hyper-city has become a dystopian counter-site that archives and represents real-world realities and simultaneously comments on them through a speculative, hyperbolic lens. Indeed, Blade Runner's effective visual shorthand of the dysfunctional city has moved into mainstream culture through recent films such as Blade Runner 2049 (2017) and Ghost in the Shell (2017), or the Netflix series Altered Carbon (all 2017), and become widely readable. Similarly, video games such as BioShock (2007-2013) or Dishonoured (2012-2016) have created retrospeculative dystopian heterotopias which act as narrative environments. These game spaces are legible precisely because they archive and represent real-world spaces and styles while also re-arranging them into a new, spatial narrative. As Henry Jenkins notes:

"Nonetheless, environmental storytelling creates the preconditions for an immersive narrative experience in up to four different ways: spatial stories can evoke preexisting narrative associations; they can provide a staging ground on which narrative events are enacted; they may embed narrative information within their mises-enscène; or they provide resources for emergent narratives." (Jenkins 2007, p. 57)

Narrative environments in video games, as we have seen with Syndicate, shape and sustain the gaming experience in crucial ways. BioShock's under-water city Rapture, for example, is envisioned as a failed utopia enshrined in optimistic art deco reminiscent of 1930s New York. However, what might have been a heterotopia of compensation, "constructed, and jumbled" (Foucault 1984, p. 8), is revealed to have collapsed under social irresponsibility into chaos and decay. The player, during his journey through the game space, "fills in the background narrative through exploration" (Carstocea 2017, p. 190), engaging and reading the narrative environment interactively. Markers of the cyberpunk city such as neon lights, expressionist lighting, gloom, and urban density foreshadow that this heterotopic space is not utopian, but dystopian, a portrait of the "impact of industrialized, urban modernity on the multitudes who are left behind in a competitive, capital-driven, and machine-driven environment" (Carstocea 2017, p. 190). As a speculative heterotopia, Rapture requires real-world counterparts, which it both represents and contests through juxtaposition, to be read intertextually. It is therefore "not just a world, it's an argument, drawing inspiration from a long tradition of progressive ideological parables and allegories" (Carstocea 2017, p. 190). In this way, it functions largely like neo-Victorianism and becomes a storytelling device in its own right.

We see this also in Dishonoured's city of Dunwall, tangibly inspired by Victorian London, John Atkinson Grimshaw's paintings or Gustave Doré's illustrations (GDC 2016). However, to create a dystopian tone, Dunwall also imports urban markers of regulation and control from present-day London, such as barbed wire, gated control zones, guard cabins, spiked iron chains, CCTV, door blockers, and signage (cf. GDC 2016). It also uses the aesthetics of the cyberpunk hyper-city to create a claustrophobic, fortified, dystopian atmosphere. Dunwall represents, but also inverts and remixes a variety of urban aesthetics into a counter-site "juxtaposing in a single [non-]real place several spaces, several sites that are in themselves incompatible" (Foucault 1984, p. 6). New meanings arise from juxtaposition and reference, as well as the audience's media literacy (Lessing 2008, p. 74; Jenkins 2008, pp. 175-77). Much like Donna Haraway's cyborg and indeed steampunk itself, which may contain "contradictions that do not resolve into larger wholes" and hold "incompatible things together because both or all are necessary and true" (Haraway 2000, p. 291), The Order' London also references and remixes different heterotopic aesthetics, namely neo-Victorianism and cyberpunk, to create environmental textures that convey key narrative functions such as setting, tone, or backstory through a recognisable visual identity. 


\section{Blade Runnering the Victorian City}

The Order's neo-Victorian London is remixed with trappings of the Blade Runner city: Layered skylines, blue-tinted colour palettes, neon advertisements, and rain and smog complement a vertically expanded Victorian London populated by heavy Gothic-brutalist skyscrapers, "mooring towers and lighthouses", and urban canyons, "inspired by the height and scale of Blade Runner" (Ellis and Weerasuriya 2015, p. 139). By importing an established Blade Runner cypher of "dark tones, crowded streets, and oppressive atmosphere" (Ellis and Weerasuriya 2015, p. 143), The Order both recognises and re-imagines London as the original hyper-city. The aesthetic suggests, in a way that resonates powerfully with established Victorian and neo-Victorian imaginaries, that this is a city whose architectural stratification mirrors the gap between wealth and poverty, that below its confident grandeur hide, not only clumsy and eclectic physical urban trappings such as wires, constructions sites, and elevated train tracks, or the barrels, papers, advertisements, and signage we encounter everywhere, but also a shabby underbelly-here, the East End. The cyberpunk visual language therefore re-encodes and highlights what is already true or imagined to be true about the Victorian city, while also adding new, speculative impulses.

Both setting and game narrative put into play Kohlke and Gutleben's claim that "neoVictorian crime and/or detective fictions, [are] quintessentially urban genres, in which cities simultaneously function as emblems of advanced civilisation, culture, and progress and of atavistic corruption that threatens their undoing" (Kohlke and Gutleben 2015, p. 20). As Galahad a Knight of the Order, we start the game by hunting Gothic monsters (here lycans or werewolves) escaped from the derelict East End to fashionable Mayfair. We return to a Westminster Palace that houses the medieval splendour of the Order of Knights and hides in its cellars a steampunk laboratory in which Nikola Tesla builds steampunk gadgets for us. Initially, The Order's London seems to offer a fantastical neoVictorian collage configured as an interactive playground in which the steampunk aesthetic comes to life. Our lycan-hunting expedition to a gloomy, ramshackle and decrepit East End, configured as a "breeding ground for rebellion" (Ellis and Weerasuriya 2015, p. 192), mobilises familiar Victorian and neo-Victorian Gothic stereotypes as a resonant backdrop for gameplay specific to the area: We engage with multilevel spaces for combat in which the "shoddy renovation" and "rundown state of buildings" become obstacles to engage with or provide new pathways (Ellis and Weerasuriya 2015, p. 194). Unlike in Syndicate, the absence of navigational interfaces and $\mathrm{x}$-ray vision simulates an immersive experience of urban guerrilla warfare at ground level. This often incomplete perspective forces us to re-evaluate the environment hermeneutically at every turn.

The game continues in a tone of adventure when we, with the heroic bravado of adventurers and James Bond-esque special agents, board and hijack a United India Company airship floating high above London and allegedly infiltrated by rebels. However, this sequence also heralds a change in tone when hints at a conspiracy are discovered and the airship crashes into the Crystal Palace in Hyde Park, killing Galahad's mentor. Back at in Westminster, Galahad's desperado temperament shipwrecks against the rigid authoritarianism of the Order, revealing frictions in the glorious-seeming surface. Just then, Galahad is called to fight a rebel ambush on Westminster bridge, which we discover is a war zone. Turned-over carriages and empty omnibuses, roadblocks, and sandbag barricades hint towards a backstory that is never explained, but hint at a London transformed by civil war and domestic terror that has reached the heart of its political power. This impression is enhanced by Galahad's requesting help from a sentinel airship that hints more powerfully at domestic surveillance. Here, the urban texture acts as a clue and a warning, subverting our initial impression of a steampunk London characterised by adventure and discovery. Instead, there is an element of disorientation and uncertainty which reminds us that we must actively interpret the steampunk cityscape.

As Galahad disobeys orders to pursue a private vendetta with the rebels, we transition from the spaces of (imagined) civilisation and order, already in a state of chaos, to the counter-space of London's East End, which so becomes a heterotopic counter-point to 
the heterotopia of steampunk London, from where the marginalised enact their rebellion. This challenge and subversion of the hegemonic spaces occupied by the Order and the United India Company is effectively embodied through the historic Rani Lakshmibai of Jhansi who, in keeping with steampunk's fantastic collage, has progressed from resistance leader of the Indian Mutiny (1857-1858) to that of the East End rebels. Her presence creates a resonant, postcolonial counterpoint to the powerful United India Company and also gives voice and agency to the marginal, colonial subject. As such, she claims that the Order has "been betrayed" by its "masters" through secrets kept from them and calls the Order "an Empire of bootlickers grovelling at the feet of the mighty United India Company" (SHN Survival Horror Network 2015, 2:57:00). The East End is configured as a heterotopia of crisis, or perhaps even one of incompatibility and exile, as it houses those who find themselves in conflict with the dominant society and have been confined to a counter-city at the (social and geographical) margins, lest their disruption of the status quo (for example through disease, poverty, or crime) contaminate the rest (Foucault 1984, pp. 5-6).

The borders of this heterotopia grow indistinct as Galahad agrees to hear Lakshmibai's argument, which leads us to interrogate urban spaces that enshrine the United India Company's power more closely by infiltrating them. In the docklands, designed to impress the players with "the influence and power wielded by the United India Company on both London and the rest of the world" (Ellis and Weerasuriya 2015, p. 244), we discover that the Company is exporting lycans and vampires to colonial territories. Hence, as the Rani tells Galahad, "Your honourable corporation spreads the very scourge you have so valiantly sworn to fight" (SHN Survival Horror Network 2015, 2:57:24). The Company, with its private army of guards and secretive interests in India, becomes the steampunk version of the ruthless global corporations which operate in cyberpunk narratives, and encodes its colonial affairs and economic interests into a sinister metaphor. The vampire may after all be read as a creature whose preying on others is physical as well as economic or political. The discovery also calls into question the status quo that we as Galahad have hitherto adhered to, as well as the boundaries that status quo allots. Whereas this cynical inversion has already been hinted at by the dystopian impulses of the Blade Runner aesthetic, these impulses now begin to come to the forefront.

In an attempt to expose the Company's sinister machinations and "strike at the very heart of the Empire" (SHN Survival Horror Network 2015, 3:48:50), Galahad infiltrates United India House, the Company's headquarters in Mayfair, now doused in murky, rainy darkness and sporadically illuminated. The palatial compound enshrines a power that now no longer seems grand, but treacherous and corrupt, and the uncertainty engendered by the plot is effectively externalised into the visual obscurity of the Blade Runner city. As with the dominant narrative about goodness and order against rebellion, the urban environment can no longer be read at face value but must be questioned and literally interrogated. As heightened, visually encoded virtual heterotopias, game spaces may invite us to question the realities they mirror in ways that real-life heterotopias cannot, because they may mobilise resonant retro-speculative or remixed aesthetics or, like the steampunk city, re-arrange and re-design urban spaces at will.

In so doing, The Order disorients and displaces our mental maps of (Victorian) London and challenge our own imagined place in it. Frederic Jameson develops his notion of cognitive mapping from Louis Althusser's definition of ideology as "the representation of the subject's Imaginary relationship to his or her Real conditions of existence": "Surely this is exactly what the cognitive map is called upon to do in the narrower framework of daily life in the physical city: to enable a situational representation on the part of the individual subject to that vaster and properly unrepresentable totality which is the ensemble of society's structures as a whole" (Jameson 1991, p. 51). In the steampunk London of The Order, that situational representation becomes increasingly uncertain as our avatar Galahad deviates from the legitimate pathways and his clandestine, nightly investigation as well as his alliance with the rebels, re-configures his relationship with 
society in tandem with urban space. Yet, it is the hegemony as represented by the United India Company and Lord Hastings that is called into question.

Indeed, in a surprising but inevitable twist, we discover that Lord Hastings, the head of the Company, is not only a vampire himself, but also the notorious Whitechapel killer Jack the Ripper. Through this hyperbolic synthesis of Gothic tropes, Victorian stereotypes, and popular conspiracy theories, namely that the Ripper turns out to be a slumming aristocrat, the game again invokes the vampire's blood lust as a metaphor for social and economic exploitation, powerfully spatialised between a hypocritical and greedy aristocracy and the disenfranchised East End: In Lakshmibai's words, Whitechapel has, quite literally, "become the country's feeding ground" (SHN Survival Horror Network 2015, 3:33:06). Through this turn of events, The Order's steampunk London, the heart of the Empire, is revealed to be corrupted through Gothic monsters who prey on the disenfranchised in their quest for power, and is re-posited as a corrupt Gothic other. The game's cityscape has continuously foreshadowed such a dystopian, even fatalist outlook through the Blade Runner aesthetics of over-powering vastness, towering spires, and pervasive, bleak atmosphere.

After Galahad is betrayed by fellow knight Alastair, himself a werewolf, he is imprisoned under Westminster Palace, breaks out, and undergoes a symbolic rebirth as Grayson, no longer a knight, but an outlaw now fully allied with the heterotopic spaces of rebellion and exile. Accordingly, we now move through heterotopic counter-spaces underneath Westminster palace, that is "dark and invisible" tunnels where "revolutionary ideas" may "ferment, undisturbed by above-world convention" and which literally undermine the hegemonic spaces above (Dobrasczyk 2019, pp. 141, 159). Here, we fight Alastair in a final, so-called "boss battle", and in line with the heterotopic character of the space, that battle is characterised by uncertainty and the erosion of boundaries. Alastair claims that "we fight only for our right to live" and that "[m]y kind are no more evil than yours" (SHN Survival Horror Network 2015, 5:06:20-5:01:30). His final soliloquy calls the binaries of good and evil into question: "I have lived too long not to know this day would come. [ ... ] I have seen things I am condemned to remember. Civilisations born and destroyed by humanity's incessant greed. The pride of men slaughtering each other in the name of their so-called God ... " (SHN Survival Horror Network 2015, 5:05:35-5:05:45). His speech echoes Roy Batty's 'Tears in Rain' death soliloquy in Blade Runner: "I've seen things you people wouldn't believe. Attack ships on fire off the shoulder of Orion. I watched Cbeams glitter in the dark near the Tannhäuser Gate. All those moments will be lost in time, like tears in rain. Time to die" (Scott [1984] 2007, 1:42:17-1:43:10). Batty's status as replicant has, in the world of the film, denied him claims to humanity, yet his final acts and words humanise him. Alastair's words likewise call the certainties of society into question, blur boundaries, and render Grayson's victory, once achieved by the player, profoundly ambivalent.

Indeed, this final fight does not rehabilitate Grayson, who now knows too much, but irrevocably exiles him to the heterotopic spaces of exile occupied by the rebellion. Accordingly, the epilogue delivers an inverted parallel shot of Grayson looking over the city at night and in classic lone vigilante manner before an apocalyptic, starkly lit cityscape: This steampunk London has become a nightmare city characterised by corruption and civil war. Grayson renounces his title as Galahad, looking out at a subverted counter-city. No longer confined to the margins, the entire city, especially as seen by night, has become an ambiguous counter-city where the dominant narrative of order and righteousness is called into question from the heterotopic position we now occupy. If at the beginning of the game we subscribed to the view that the East End was a heterotopic other, our immersed journey through steampunk London and our engagement with its narrative texture have now led us to a perspective from which the hegemonic spaces are exposed as illusory.

The Order exemplifies how a steampunk narrative environment may shape and determine the central narrative and even become an argument in and of itself. The heterotopic counter-space of the steampunk game here takes us on a journey spatialised into an alternative city and invites us to explore, examine and question not only the status quo 
presented of the game, but our own memories and assumptions about the Victorian imaginary and the present city. The Order lures us in with adventure tropes and then makes us confront a labyrinthine steampunk setting full of blind spots and false promises, thereby literalising the steampunk thought experiment into an immersive and interactive spatial simulation. By remixing a Victorian imaginary of memory with futuristic cyphers of cyberpunk, the game creates a heterotopic setting that is no longer a fixed memory enshrined in the past, but, like space itself, is constantly being made and re-made in dialogue with the present and demands constant hermeneutic re-evaluation. The game invites us to question political power structures, corporate control, or colonial legacies that play out resonantly in neo-Victorian contexts, but likewise inform the cyberpunk aesthetic. Through their visual, spatial, and narrative confluence, both modes create a heterotopic steampunk London that speaks more universally to the legacies of the nineteenth century and the neoliberal era in the globalised present.

\section{Conclusions: Steampunk as a Spatial Argument}

Both Assassin's Creed: Syndicate and The Order 1886 mobilise popular imaginaries of Victorian London to enact steampunk game spaces as interactive heterotopias. Their virtual Londons are sourced from a shared imaginary of the Victorian city, so that they represent and archive collective memory, but also re-imagine and subvert them through retro-speculative impulses.

Syndicate re-imagines Victorian London as a historical playground in which we roam freely as assassin-outlaws and underdog heroes, setting right the wrongs of the past. This of course reveals a simplified and patronising approach to the socio-economic complexities of that past in favour for an alternative, empowering urban experience, in which clear choices can be made and we come to know a neo-Victorian London in ways we cannot know either the historical or the contemporary city. The game realises the city as a heterotopia of compensation, readable and knowable, well-arranged as both a city of hindsight and a finitely coded narrative setting. Our avatar's access to birds-eye views places us within our mental map of past and city alike in a position to monitor and understand comprehensively. This mobilisation of cognitive mapping also informs the parkour-inspired movements which create heterotopic journeys within the virtual city which help expose and challenge real-life London's heavily regulated urban spaces.

The Order, by contrast, renders triumphs over the traumas of the past difficult. Instead, it provides a steampunked cityscape we must actively (re-)interpret through its environments and aesthetics as we journey through it. It enacts a heterotopic challenge and potential subversion of hegemonic spaces at ground level through a trajectory from the centre to the margin and configuring Victorian London as a whole as an ambiguous space. Its systemic failures such as a corrupt government, capitalist exploitation of a working class that is literally fed on, or colonialist greed are located, not in a historically mimetic neo-Victorian setting, but instead a steampunk London infused with cyberpunk aesthetics, where the timelines between past, present, and future collapse.

The game enacts a more complex understanding that these wrongs, which still have tangible repercussions in the player's present cannot easily be recognised, defeated, or set right. On the contrary, whereas Syndicate offers and experience of freedom and mastery, The Order's trajectories open up new perspectives, but also lead into exile. Yet, while this is not a neo-Victorian past that we may master, but instead one whose dominant narratives must be interrogated, challenged, and sometimes even subverted, the game also suggests that the heterotopic, outlaw spaces offer an enhanced, empowering view of the city.

Steampunk game space heterotopias offer playful, immersive, and embodied-by-proxy thought experiments and provide an adventurous, entertaining, and defamiliarising lens through which we may re-evaluate the real world - not because they imagine a possible alternative, but because they challenge and subvert the ways in which we have come to remember it. Putting cognitive mapping literally into play, they invite us to re-evaluate not only our position in the virtual city, but also the stratified power it enshrines, as well 
as our position towards past, present, and even future. In this endeavour, the steampunk mode itself becomes a kind of heterotopic counter-site, "in which the real sites, all the other real sites that can be found within the culture, are simultaneously represented, contested, and inverted" (Foucault 1984, p. 3). After all, as Bruce Sterling comments on steampunk, "the past is a kind of future that has already happened" (Sterling 2011, p. 13).

Funding: This research received no external funding.

Institutional Review Board Statement: Not applicable.

Informed Consent Statement: Not applicable.

Data Availability Statement: Not applicable.

Conflicts of Interest: The author declares no conflict of interest.

\section{References}

Aarseth, Espen. 2007. Allegories of Space. The Question of Spatiality in Computer Games. In Space Time Play. Computer Games, Architecture, and Urbanism: The Next Level. Edited by von Borries Friedrich, Steffen P. Walz and Matthias Böttger. Berlin: Birkhäuser Verlag, pp. 44-47.

Ameel, Lieven, and Sirpa Tani. 2012. Parkour: Creating loose spaces? Geografiska Annaler: Series B, Human Geography 94: 17-30. [CrossRef]

Baudrillard, Jean. 1983. Simulations. Translated by Foss Paul, Paul Batton, and Philip Beitchman. Los Angeles: Semiotext(e). First published 1981.

Brooker, Will. 2005. Introduction: 2019 Vision. In The Blade Runner Experience. The Legacy of a Science Fiction Classic. Edited by Will Brooker. London and New York: Wallflower Press, pp. 13-24.

Bruno, Giuliana. 1987. Ramble City: Postmodernism and "Blade Runner". October 41: 61-74. [CrossRef]

Carstocea, George. 2017. Uchronias, Alternate Histories, and Counterfactuals. In The Routledge Companion to Imaginary Worlds. Edited by Wolf Mark J. P. New York: Routledge, pp. 184-91.

Clute, John. 1996. Look at the Evidence: Essays and Reviews. Liverpool: Liverpool University Press.

Csiscery-Ronay, Istvan. 2011. The Seven Beauties of Science Fiction. Middletown: Wesleyan University Press.

Daskalaki, Maria, Alexandra Starab, and Miguel Imasa. 2008. The 'Parkour Organisation': Inhabitation of corporate spaces. Culture and Organization 14: 49-64. [CrossRef]

Davies, Paul. 2015. The Art of Assassin's Creed: Syndicate. London: Titan Books.

Dehane, Michiel, and Lieven de Cauter. 2008. Heterotopia and the City. Public Space in a Postcivil Society. London: Routledge.

Devinsupertramp. 2015. Assassin's Creed Syndicate Meets Parkour in Real Life! Video, 0:03:44. Posted by Devin Graham. Available online: https: / / www.youtube.com/watch?v=HFRscoOkkb8 (accessed on 15 February 2020).

Dickens, Charles. 1986. Nicholas Nickleby. Edited by Michael Slater. London: Penguin. First published 1838.

Dobrasczyk, Paul. 2019. Future Cities: Architecture and the Imagination. London: Reaktion Books.

Ellis, Kirk, and Ru Weerasuriya. 2015. The Blackwater Archives. The Art of The Order: 1886. San Francisco: Bluecanvas, Inc.

Foucault, Michel. 1984. Of Other Spaces. Translated by Jay Miskowiec. In Architecture/Mouvement/Continuité. pp. 1-9, Unpublished lecture, given 1967.

GDC. 2016. World of Dishonored: Raising Dunwall. Video, 0:55:56. Posted 22 February 2016. Available online: https:/ / www.youtube. com/watch?v=LOQDbSvpFtY (accessed on 15 February 2020).

Gibson, William. 2016. Neuromancer. London: Gollancz. First published 1984.

Götz, Ulrich. 2007. Load and Support. Architectural Realism in Video Games. In Space Time Play. Computer Games, Architecture, and Urbanism: The Next Level. Edited by von Borries Friedrich, Steffen P. Walz and Matthias Böttger. Berlin: Birkhäuser Verlag, pp. 134-37.

Haraway, Donna. 2000. A Cyborg Manifesto. Science, Technology and Socialist-feminism in the Late Twentieth Century. In The Cybercultures Reader. Edited by David Bell and Barbara M. Kennedy. London: Routledge, pp. 291-324.

Harvey, David. 2012. Rebel Cities. From the Right to the City to the Urban Revolution. London: Verso.

Jameson, Frederic. 1991. Postmodernism. Or, The Cultural Logic of Late Capitalism. London: Verso.

Jenkins, Henry. 2007. Narrative Spaces. In Space Time Play. Computer Games, Architecture, and Urbanism: The Next Level. Edited by von Borries Friedrich, Steffen P. Walz and Matthias Böttger. Berlin: Birkhäuser Verlag, pp. 56-60.

Jenkins, Henry. 2008. Convergence Culture. Where Old and New Media Collide. New York: New York University Press.

Kohlke, Marie-Louise, and Christian Gutleben. 2012. The (Mis)Shapes of Neo-Victorian Gothic: Continuations, Adaptations, Transformations. In Neo-Victorian Gothic. Horror, Violence, and Degeneration in the Re-Imagined Nineteenth Century. Edited by Marie-Louise Kohlke and Christian Gutleben. Leiden: Brill Rodopi, pp. 1-50.

Kohlke, Marie-Louise, and Christian Gutleben. 2015. Troping the Neo-Victorian City. In Neo-Victorian Cities. Reassessing Urban Politics and Poetics. Edited by Kohlke Marie-Louise and Christian Gutleben. Leiden: Brill Rodopi, pp. 1-42.

Lessing, Lawrence. 2008. Remix. Making Art and Commerce Thrive in the Hybrid Economy. London: Bloomsbury. 
Levebvre, Henri. 1996. The Right to the City. In Writings on Cities. Edited by Eleonore Kofman and Elizabeth Lebas. London: Blackwell. First published 1968.

Levebvre, Henri. 1991. The Production of Space. Oxford: Basil Blackwell.

Luckhurst, Roger. 2005. Science Fiction. Cambridge: Polity Press.

Makai, Péter Kristóf. 2018. Video Games as Objects and Vehicles of Nostalgia. Humanities 7: 123. [CrossRef]

Massey, Doreen. 2005. For Space. London: SAGE Publications.

MrBlockzGaming. 2019. Assassin's Creed Syndicate FULL Walkthrough No Commentary Gameplay Part 1 Longplay (PC). Video, 13:26:04. Posted January 14. Available online: https:/ /www.youtube.com/watch?v=41WnPg6ve88 (accessed on 15 February 2020).

Nead, Lynda. 2000. Victorian Babylon. People, Streets and Images in Nineteenth-Century London. New Haven and London: Yale University Press.

Nieslen, Holly. 2015. Reductive, superficial, beautiful-A historian's view of Assassin's Creed: Syndicate. The Guardian. December 9. Available online: https://www.theguardian.com/technology/2015/dec/09/assassins-creed-syndicate-historian-ubisoft (accessed on 15 February 2020).

Palladino, Mariangela, and John Miller. 2015. The Globalization of Space: Foucualt and Heterotopia. London: Routledge.

Perschon, Mike. 2018. Steampunk FAQ. All That's Left to Know about the World of Goggles, Airships, and Time Travel. Plymouth: Applause Theatre E Cinema Books.

Ready At Dawn. 2015. The Order 1886. Developed by Ru Weerasuriya. PlayStation 4. Tokyo: Sony Computer Entertainment.

Rowley, Stephen. 2005. False LA: Blade Runner and the Nightmare City. In The Blade Runner Experience. The Legacy of a Science Fiction Classic. Edited by Will Brooker. London and New York: Wallflower Press, pp. 203-12.

Scott, Ridley. 2007. Blade Runner. Final Cut. Los Angeles: Warner Borthers Entertainmens. DVD. First published 1984.

SHN Survival Horror Network. 2015. The Order: 1886 Full HD PS4 Longplay [1080p/60fps] Walkthrough Gameplay Lets Play No Commentary. Video, 5:15:27. Posted 23 February 2015. Available online: https:/ /www.youtube.com/watch?v=WI_dnwhn9s0 $\& \mathrm{t}=1451$ s (accessed on 15 February 2020).

Soja, Edward. 2000. Postmetropolis. Critical Studies of Cities and Regions. Oxford: Blackwell Publishers.

Sterling, Bruce. 2011. The User's Guide to Steampunk. In The Steampunk Bible. An Illustrated Guide to the World of Imaginary Airships, Corsets and Goggles, Mad Scientists, and Strange Literature. Edited by VanderMeer Jeff and S. J. Chambers. London: Abrams \& Chronicle Books, pp. 12-13.

TEAMSUPERTRAMP. 2015. Behind The Scenes-Assassin's Creed Syndicate Meets Parkour in Real Life. Video, 0:12:08. Posted by Devin Graham, 6 July 2015. Available online: https:/ / www.youtube.com/watch?v=c2dlOR4CdR4 (accessed on 15 February 2020).

Ubisoft. 2015. Assassin's Creed: Syndicate, Directed by Marc-Alexis Côté, Scott Phillips and Wesley Pincombe. PlayStation 4. Ubisoft.

Voigts-Virchow, Eckart. 2009. In-yer-Victorian-face: A Subcultural Hermeneutics of Neo-Victorianism. Lit: Literature Interpretation Theory 20: 108-25. [CrossRef]

Webster, Andrew. 2019. Building a better Paris in Assassin's Creed Unity. Historical accuracy meets game design. The Verge, 17 April 2019. Originally published 31 October 2014. Available online: https://www.theverge.com/2014/10/31/7132587/assassinscreed-unity-paris (accessed on 15 February 2020).

Whalen, Zach, and Laurie N. Taylor. 2008. Playing the Past: History and Nostalgia in Video Games. Nashville: Vanderbilt University Press. 